\title{
Contact with Isolated Sclerotome Cells Steers Sensory Growth Cones by Altering Distinct Elements of Extension
}

\author{
Michael B. Steketee ${ }^{1}$ and Kathryn W. Tosney ${ }^{2}$ \\ Departments of ${ }^{1}$ Neuroscience and ${ }^{2}$ Biology, The University of Michigan, Ann Arbor, Michigan 48109
}

During pathfinding, growth cones respond to guidance cues by altering their motility. This study shows that motile responses can be highly specific: filopodial contact with two different, physiologically relevant cells differentially alters discrete elements of motility. With each cell type, the responses to contact are invariant. Each cell induces a distinct response in sensory growth cones with every filopodial contact. Contact with an inhibitory cell, posterior sclerotome, alters a discrete motile characteristic; contact locally inhibits the ability of veils to extend down contacting filopodia. The inhibition is precise. Contact fails to alter other individual veil characteristics such as initiation frequency or extension rate. Moreover, despite local veil inhibition, the general level of extension across the growth cone is retained, as though protrusive activity is regulated to some set point. Contact with a stimulatory cell, anterior sclerotome, elicits a biphasic response. First, contact stimulates extension generally, altering the set point of protrusion. Contact increases veils and filopodia throughout the growth cone persistently. Then contacting processes consolidate, forming neurite. Filopodia contacting either cell type have similar lifetimes but different fates. Filopodia contacting posterior cells show morphological indications of structural instability, likely related to their inability to support veil extension. Filopodia contacting anterior cells branch, become morphologically complex, and ultimately consolidate into neurite. The invariance and precision of these responses suggests they are the steering components elicited by contact. These steering components, when integrated with other motile events, modulate growth cone trajectory. The discreteness of these responses suggests that guidance cues affect equally discrete elements in signaling cascades.

Key words: sensory neurons; axon guidance; growth cone; growth cone guidance; motility; filopodia; veils
Cues guide developing neurites over complex, stereotyped pathways by affecting their pathfinding organ, the growth cone. To change a growth cone's direction of travel, cues must alter the growth cone's motility selectively, possibly by modulating one of the three motile events that Goldberg and Burmeister (1986) suggest mediate growth cone advance. First is extension. Growth cones extend two types of cellular processes: filopodia (finger-like processes) and veils (sheet-like processes that extend between filopodia). Veil and filopodial extension are essential to pathfinding because inhibiting their extension completely causes growth cones to advance aimlessly (Marsh and Letourneau, 1984; Bentley and Toroian-Raymond, 1986; Chien et al., 1993). When extension is locally promoted or inhibited (Bastmeyer and Stuermer, 1992; Oakley and Tosney, 1993; Fan and Raper, 1995; Zheng et al., 1996; Ming et al., 1997), growth cones are steered precisely. Second is engorgement. Veils and filopodia may engorge with cytoplasm. Because not all extensions engorge (Goldberg and Burmeister, 1986), cues may also steer by influencing engorgement (Smith, 1994). Third is consolidation. Engorged regions can consolidate, transforming growth cone into neurite. Because not all engorged regions consolidate (Goldberg and Burmeister, 1986), cues may also steer by modulating consolidation (Oakley and Tosney, 1993).

These motile events can be modulated selectively, and on a

\footnotetext{
Received Aug. 3, 1998; revised Feb. 10, 1999; accepted Feb. 10, 1999.

This research was supported by National Institutes of Health Grant NS 21308. We thank K. Balazovich, S. Easter, E. Feldman, R. Hume, and L. Foa for comments.

Correspondence should be addressed to K. W. Tosney, Department of Biology, Natural Science Building, 830 N. University, The University of Michigan, Ann Arbor, MI 48109-1048.

Copyright (C) 1999 Society for Neuroscience $0270-6474 / 99 / 193495-12 \$ 05.00 / 0$
}

very fine scale, by physiologically relevant cues that guide motoneurons. In vivo, motor growth cones encounter two cellular populations: anterior sclerotome (AS) cells that permit their advance and posterior sclerotome (PS) cells that prohibit their advance (for review, see Tannahill et al., 1997). In culture, contact with either sclerotome cell type differentially alters motor growth cone motility (Oakley and Tosney, 1993). Contact with a posterior sclerotome cell inhibits veil extension locally, whereas contact with an anterior sclerotome cell first stimulates veil and filopodial extension across the growth cone and then stimulates contacting extensions to consolidate locally. Each alteration is invariant, a constant consequence of contact. These alterations bias trajectory toward anterior and away from posterior sclerotome cells, mirroring motor axon behavior in vivo.

Sclerotome cells provide "general cues" that guide dissimilar populations along common paths, unlike specific cues that guide populations at points where common paths diverge (for review, see Tosney, 1991). We therefore began this study to ask whether sclerotome cells elicit the same changes in another population that encounters them in the embryo. We found that they do. Sclerotome cells elicit the same changes in sensory as in motor growth cones. Moreover, we show that these responses are induced by direct contact because fixed sclerotome cells evoke the same responses. Thus, general cues guide both sensory and motor growth cones by inducing the same set of motile alterations on contact.

By focusing on these fine but invariant alterations, we can dissociate the direct consequences of contact from the overall behavioral responses, like turning or stopping, which result from integrating multiple motile events. Our analysis of these invariant 
events reveals five new findings. (1) Growth cones regulate their protrusive activity about a set point; (2) cues can reset the set point, e.g., persistently increasing extension across the growth (3) extension is localized according to a hierarchy of preferred sites, with the leading edge generally being dominant; (4) cues can alter very fine aspects of motile dynamics, e.g., inhibiting veil stability without altering veil initiation; and (5) cues can alter filopodial fates, initiating discernible morphological changes in filopodia that are unrelated to overall filopodial lifetime or to the duration of adhesion.

\section{MATERIALS AND METHODS}

\section{Cell culture}

Sclerotome cells. Chick embryos [stage 17-18; Hamburger and Hamilton (1951)] were dissected as described previously (Oakley and Tosney, 1993). Small explants were aspirated from either the anterior or posterior somite with a flame-polished electrode (tip diameter, $50 \mu \mathrm{m}$ ), washed in neuron media (NM) composed of Ham's F12 (Life Technologies, Grand Island, NY) supplemented with $10 \%$ horse serum, antibiotics, and hormone additives (Bottenstein et al., 1980), plated on polyornithine/ laminin-coated (Life Technologies) glass coverslips, and maintained at $37^{\circ} \mathrm{C}, 5 \% \mathrm{CO}_{2}$ overnight. Culture purity was verified by lectin binding and immunocytochemistry as in Oakley and Tosney (1993). For fixed cultures, the sclerotome cells were washed in Krebs' buffer (Meiri and Burdick, 1991) with $0.4 \mathrm{M}$ sucrose (K/S), fixed with $1 \%$ paraformaldehyde in $\mathrm{K} / \mathrm{S}$ for $10 \mathrm{~min}$ at $37^{\circ} \mathrm{C}$, and washed three times with each of the following: K/S, 0.5 M glycine in PBS, pH 7.2, and NM. Despite exposure to fixative, the laminin substrate supported growth cone extension and advance as well as unexposed substrates did. Because responses are the same with fixed cells, live and fixed interactions are discussed together.

Sensory neurons. Chick embryos [stage 24-25; Hamburger and Hamilton (1951)] were washed in Ham's F12, decapitated, eviscerated, and divested of their notochord, spinal cord, and meninges. Dorsal root ganglia (DRG) were removed, washed in NM supplemented with 50 $\mathrm{ng} / \mathrm{ml}$ nerve growth factor (Calbiochem, La Jolla, CA) and $10 \mathrm{~mm}$ HEPES, and gently dissociated into small explants by pipetting. The explants were washed in $\mathrm{NM}$ and incubated at $37^{\circ} \mathrm{C}, 5 \% \mathrm{CO}_{2}$ for $\sim 3 \mathrm{hr}$. For experiments, small explants $(10-15$ cells) were added to the sclerotome cultures.

\section{Optical recording}

For recording, cultures were overlaid with $\mathrm{NM}$ and mineral oil and maintained at $37^{\circ} \mathrm{C}$ with a heated stage. Interactions were viewed with phase-contrast optics (Plan Apo 60×/1.40 DM objective, Nikon, Melville, NY) and recorded with either an intensified CCD video camera (model TM-74, Pulnix, Motion Analysis, Eugene, OR) or a Hamamatsu cooled CCD camera (model C5985, Hamamatsu Photonics, Oak Brook, IL) under control of Metamorph (Universal Imaging, West Chester, PA). Images were recorded at 15 frames/min and stored on optical disk (model 3038f, Panasonic, Secaucus, NY).

\section{Image analysis}

To characterize the gross responses to contact (the overall growth cone behavior), we examined at least eight interactions from each co-culture type. For quantitative analysis of specific responses, we selected three interactions from each co-culture type that met the following criteria. (1) The recorded precontact period lasted at least $5 \mathrm{~min}$; (2) the sclerotome cell was sufficiently flat to clearly visualize contacting processes; and (3) the interaction was asymmetric, i.e., filopodia from only one side made contact, letting us compare contacting and noncontacting filopodia on the same growth cone. To compare data from growth cones differing in size and levels of activity, data from individual growth cones were normalized by expressing the values as a percentage of the precontact mean. Because data from live and fixed interactions were the same statistically (ANOVA), they were combined for presentation.

To distinguish whether contact-dependent changes in veil extension were confined to the contact site or were spread throughout the growth cone, veils were compared on noncontacting and contacting filopodia. Veils were defined as thin sheets that extended at least $1 \mu \mathrm{m}$ between filopodia. Their movements were followed by playing the recordings forward and backward, permitting identification of both the initiation site (the point where a veil first began to extend) and the point of maximum extension (the point where a veil stopped extending). To detect contactdependent changes in individual veils, five veil characteristics were measured. (1) Veil stability was recorded as the percentage of veils that failed to retract and ultimately filled with cytoplasm as the growth cone advanced in their direction. During playback, the movement of cytoplasm into stable veils was clearly visible. (2) Veil area was measured as the surface area between filopodia after a veil reached maximum extension. Veil areas ranged from 1 to $29 \mu \mathrm{m}^{2}$ and, for contacts with AS or the substrate, averaged $6.54 \pm 2.4 \mu \mathrm{m}^{2}$. (3) Distance of veil extension was measured from the veil initiation site to its point of maximum extension; distance ranged from 1 to $13.5 \mu \mathrm{m}$ and, for contacts with AS or the substrate, averaged $4.44 \pm 1.1 \mu \mathrm{m}$. (4) Frequency of veil initiation per filopodium was calculated by dividing the number of veil initiations per filopodium by the time the filopodium was bound to the substrate or a cell; frequency of veil initiation ranged from 0 to $1.6 / \mathrm{min}$ and averaged $0.61 \pm 0.32$ initiations $/ \mathrm{min}$. (5) Rate of veil extension was calculated by dividing the distance extended by the duration of extension.

To detect changes in the overall level of extension, we compared the number of veil or filopodial initiations on noncontacting and contacting sides of the growth cone. Each side was defined by bisecting the growth cone along the axis of the neurite. On each side, the number of veil or filopodial initiations was counted for $5 \mathrm{~min}$ before and $5 \mathrm{~min}$ after stable filopodial contact. An initiation was defined as a veil or filopodium that extended for at least $1 \mu \mathrm{m}$. Over the same period, the surface area of each side, excluding filopodia and neurite, was measured every minute by loading the appropriate frame into Metamorph and then manually tracing the spread area of each side, excluding neurite and filopodia. Metamorph then calculated the area of the traced region. A mean surface area was calculated for each side by averaging the individual surface area measurements.

To detect filopodial changes on contact, we analyzed nine characteristics of attached filopodia, where attached filopodia were defined as filopodia that contacted the substrate or a cell, straightened as if under tension, and remained stationary for at least $1 \mathrm{~min}$. These criteria exclude filopodia that move over the cell without touching it, or that touch it only transiently. (1) Filopodial lifetime was recorded from first contact throughout the period when filopodial contact was maintained and a filopodial structure remained evident. Endpoints were defined by detachment or the loss of filopodial integrity through engorgement or lateral movement and fusion with other processes. (2) Filopodial rigidity was recorded as the percentage of the filopodial lifetime during which a rigid conformation was maintained. A loss in rigidity was indicated by undulations, bending, and/or thinning. Once rigidity was lost, it was not reacquired. (3) Of those filopodia that detached, percent rigid was recorded as the percentage that detached without losing rigidity. (4) Filopodial dilation was recorded as the percentage of filopodia that detectably thickened at their base. Dilation often extended into the proximal filopodium but seldom filled the entire filopodium before it branched. (5) Time to dilation was recorded for dilating filopodia as the time from initial contact to the time when the base of the contacting filopodium became noticeably phase-darker and enlarged. (6) Filopodial branching was recorded as the percentage of filopodia that extended one or more stable ( $>1$ min lifetime) filopodia; veils were not taken as indications of branching but often formed between branching filopodia. (7) For filopodia that branched, the time to filopodial branching was recorded as the time from initial contact to the initial appearance of the first persistent branch. (8) Filopodial consolidation was recorded as the percentage of filopodial contacts that became complex and ultimately condensed to form a thickened, neurite-like structure. (9) For contacts that consolidated, consolidation lifetime was recorded as the time from initial filopodial contact until the contact site was incorporated into neurite or was supplanted by a subsequent consolidation site.

\section{RESULTS}

The invariant responses to contact with each cell type are first described and documented. Then the effects of each contact are compared, first in relation to the rate of neurite advance and then in relation to the lifetime and fate of filopodia.

\section{Contact with posterior sclerotome}

Contact with PS cells alters sensory growth cone motility at a discrete location: the contact site. On contact, veils fail to extend on contacting filopodia (Fig. 1). Some elements of this response 

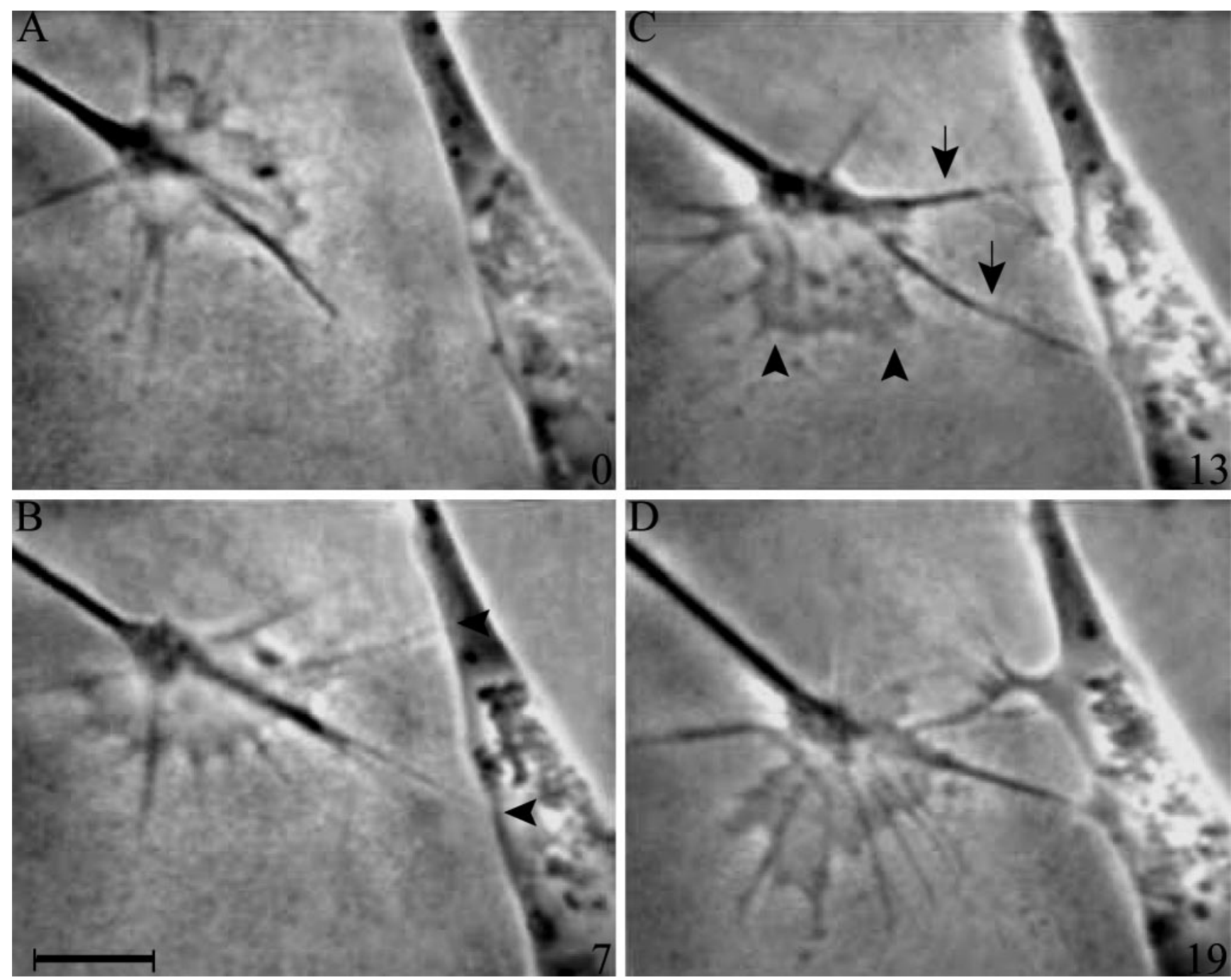

Figure 1. Contact with a live PS cell inhibits veil extension locally. $A$, Before contact, a sensory growth cone extends veils and filopodia symmetrically. $B$, Two filopodia make contact (arrowheads). C, Contact inhibits veil extension on contacting filopodia only (arrows), whereas noncontacting filopodia continue to support veil extension (arrowheads). D, As long as the filopodia remain attached, veils fail to extend locally. Time in minutes is indicated at the bottom right of $A-D$. Scale bar, $10 \mu \mathrm{m}$.

can be elucidated by general comments about the recorded interactions. For instance, if a filopodium has a veil before contact, the veil retracts as soon as stable contact is made, suggesting that inhibition is relatively immediate. Veils continue to initiate on contacting filopodia, but such veils are small, unstable, and fail to extend down contacting filopodia, suggesting a discrete effect on extension rather than on initiation. The inhibition remains local throughout the contact period. Even during prolonged contact, veils continue to extend successfully on adjacent, noncontacting filopodia, even on filopodia that had merged with the base of a contacting filopodium to create a filopodial fascicle. Filopodia that branch from these fascicles or that extend immediately alongside them can also support extension, suggesting that the signal inhibiting veil extension on contacting filopodia may be restricted to the site of contact, perhaps even to the distal filopodium. Fixed PS cells evoked the same response as live PS cells (Fig. 2).

Veil inhibition on contact is invariant. Veils abort on contacting filopodia in every PS interaction. Moreover, the response does not desensitize. Even during prolonged interactions (up to $2 \mathrm{hr}$ ), each contact with the same or another PS cell reiterates the response. For instance, in three interactions, a second PS cell was contacted; all three responded as if they were contacting a PS cell for the first time. The invariance of this response suggests that it is the most proximate and relevant response to the guidance cue.

Contact with PS cells disrupts three discrete elements of veil extension that are quantitative measures of the ability of veils to extend down filopodia: stability, area, and distance. Contact locally reduced veil stability (Fig. $3 A$ ). On noncontacting filopodia, $30 \%$ of veils were stable. They extended and then subsequently filled with cytoplasm, advancing the growth cone in their direction. In contrast, only $2 \%$ of the veils on contacting filopodia filled. In addition, compared with the precontact mean, veils on contacting filopodia were smaller (Fig. 3B) and failed to extend as far as veils on noncontacting filopodia (Fig. $3 C$ ).

Two veil characteristics remained unchanged by contact: initiation frequency per filopodium and rate of extension. Whether a filopodium was bound to the substrate or to a PS cell, veils initiated at the same frequency (Fig. 3D). Contact also failed to alter how quickly veils extended down filopodia. Veils extended at the same rate $(6.9 \pm 2.1 \mu \mathrm{m} / \mathrm{min})$ on filopodia contacting the 

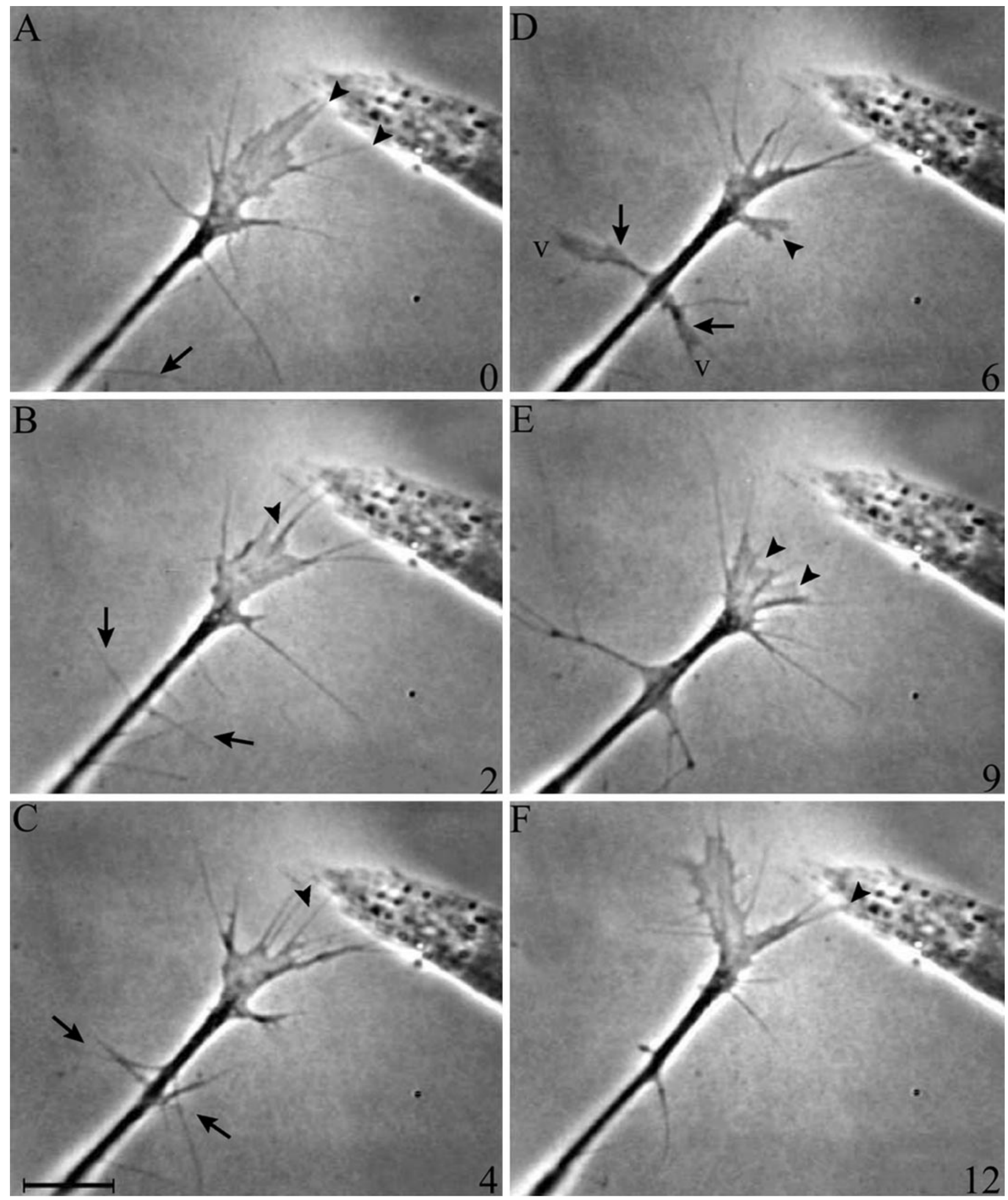

Figure 2. Contact with a fixed PS cell inhibits veil extension locally. A, A sensory growth cone contacts a fixed PS cell (arrowheads). B, Once contact is made, veils on contacting filopodia retract (arrowhead). C, Veils fail to extend on contacting filopodia (arrowhead). D, Veils extend on noncontacting filopodia (arrowhead). E, Loss of contact relieves veil inhibition. Within $2.5 \mathrm{~min}$ of losing contact, veil extension is restored to the leading edge (arrowheads).F, The growth cone reestablishes contact, reiterating the response; veil extension is inhibited on contacting filopodia (arrowhead), whereas noncontacting filopodia support extension. Consequently, the growth cone advances away from the site of contact. These (Figure legend continues) 
laminin substrate or a PS cell (Fig. 3E). Therefore, local veil inhibition is not caused by fewer initiations or slower extension.

Surprisingly, despite the local veil inhibition, growth cones contacting PS cells retain relatively constant levels of extension and thus a constant area overall, as though their level of extension were regulated to a set point (Fig. 4). When contact reduces extension locally, growth cones compensate by increasing extension at other sites that are recruited hierarchically, based on the site and degree of contact. When contact and thus inhibition are confined to a portion of the leading edge, extension increases from noncontacting sites at the leading edge (Fig. 1C,D). When more filopodia contact, extension is redirected to the sides. When the entire leading edge contacts and all previous extension is inhibited, extension is often redirected to the base of the growth cone or the neurite, which then extends new filopodia and veils (Fig. 2D).

This redirection of extension integrates with the local inhibition to amplify overall avoidance behaviors. Before contact, growth cones extend veils relatively symmetrically and thus advance along a relatively straight trajectory. After contact, veil extension is biased away from contacting filopodia (Figs. 1, 2). Consequently, sensory growth cones advance away from PS cells. For instance, growth cones that contact at oblique angles are inhibited at one side; the redirection of veil extension to the other side contributes to turning $(n=9)$. Growth cones contacting with a central portion of their leading edge branched $(n=5)$, or, if their entire leading edge contacted, they stopped and often extended new processes distally, thus producing one or more potential branches distal to the site of contact $(n=6)$. All three avoidance responses-turning, branching, and stopping-arise from the asymmetry in veil extension, which is a product of contact-induced veil inhibition and redirected extension.

Despite the lability of extension, the leading edge is the preferred site for extension, because when filopodia at the leading edge detach from PS cells, veil extension is rapidly restored to the leading edge (Fig. 2E). This hierarchy of preferred extension sites, highest at the leading edge and lowest at the neurite, suggests that growth cones maintain set levels of veil and filopodial extension by redirecting extension to progressively lower priority sites until their set point is restored.

\section{Contact with anterior sclerotome}

Like motor growth cones, sensory growth cones respond biphasically to contact with AS cells, first increasing veil and filopodial extension generally and then consolidating at the contact site (Fig. 5). General attributes of this response will be described before the quantitative analysis is detailed. In the first phase, extension is stimulated rapidly and generally. On contact, the number of veils and filopodia extended increases throughout the growth cone, increasing growth cone size and complexity. In the second phase, the growth cone gradually consolidates at the contact site. Contacting veils and filopodia begin to coalesce into a thick, phase-dark extension that then extends new veils and filopodia, transforming the process into a branch. This local transformation increases the growth cone's potential to extend additional processes on to the cell. As additional processes con- tact (data not shown), the response is reiterated, broadening the scope of the consolidation. Consequently, the contact site often becomes the dominant site for advance even when many processes extend in other directions. Because continuing contacts propagate the consolidation, an entire growth cone extending onto an AS cell usually adopts a streamlined morphology similar to that of motor growth cones advancing on AS cells in culture (Oakley and Tosney, 1993) or in vivo (Tosney and Landmesser, 1985). Growth cones showed the same responses to live and fixed AS cells (data not shown).

That the increases in extension are induced generally rather than locally was confirmed quantitatively by comparing the number of processes extended on noncontacting and contacting sides of the growth cone. Compared with the precontact mean, the extension of both filopodia and veils increased significantly on both sides (Fig. 6A,B). The surface area of each side also increased (Fig. 6C). Typically, contact increased filopodial extension by $75 \%$ and surface area by $59 \%$. However, in one interaction, a single contact increased filopodial extension by $165 \%$ and surface area by $265 \%$.

The increases in extension are rapid and persistent. For instance, filopodial initiations increased to $137 \%$ of the precontact values in the first minute, to $158 \%$ by the second minute, and to $186 \%$ by the fourth minute after contact. Increases could persist without additional contact, suggesting that contact with AS initiates a signaling pathway in the filopodial tip that spreads rapidly, resetting some set point that regulates the levels of veil and filopodial extension.

Although contact increases the number of veils extended throughout the growth cone, quantitative analysis showed that individual veil characteristics are unaltered. Veils extending on contacting filopodia did not differ from those on noncontacting filopodia. First, contact failed to alter veil stability (Fig. 7A). The same percentage of veils filled with cytoplasm on contacting and noncontacting filopodia. Second, contact failed to alter veil size. Compared with the precontact mean, the average area of individual veils and the distance a veil extended was unchanged (Fig. $7 B, C)$. Third, contact failed to alter the frequency of veil initiation per filopodium. Veils emerging on filopodia bound to the cell initiated at the same frequency as veils emerging on filopodia bound to the substrate (Fig. 7D). Finally, contact failed to alter the rate of veil extension (Fig. $7 E$ ). Veils extended at the same rate $(7.0 \pm 1.0 \mu \mathrm{m} / \mathrm{min})$ regardless of whether filopodia contacted the laminin substrate or an AS cell. Thus, neither the general increase in extension nor the local consolidation is explicable in terms of altered veil characteristics. Veils can influence growth cone advance on the substratum where a common mode of advance results from a gradual filling of veils. However, contact with AS cells appears to induce a more direct consolidation, altering aspects of advance independent of the dynamics of individual veils.

\section{Neurite elongation}

As with motor growth cones, contact with either sclerotome cell type reduced the rate of neurite elongation. Compared with the precontact rate, contact with a PS cell reduced the rate of elon-

figures also illustrate the redirection of extension during leading edge inhibition. $A$, On contact, a single filopodium sprouts from the previously quiescent neurite (arrow). B, Within 2 min, additional filopodia extend from the neurite (arrows) and $(C)$ fasciculate (arrows), $(D)$ forming collateral branches that extend veils $(v) . E, F$, However, as soon as veil extension resumes at the leading edge, these branches lose veils and retract. Time in minutes is indicated at the bottom right of $A-F$. Scale bar, $10 \mu \mathrm{m}$. 
A

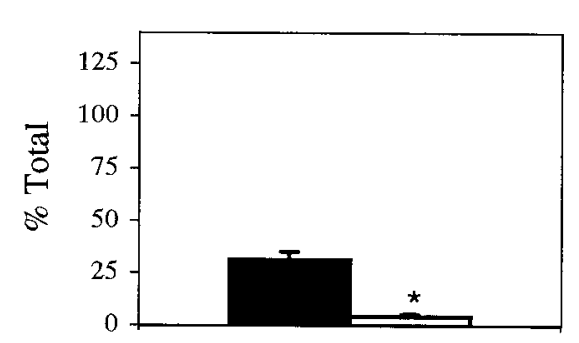

B Area

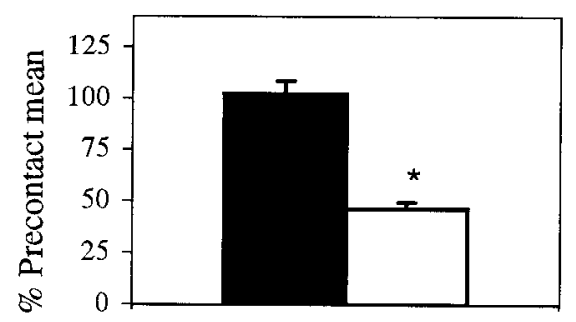

C

Extension distance

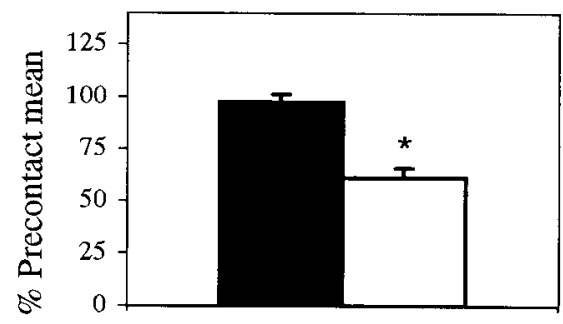

D

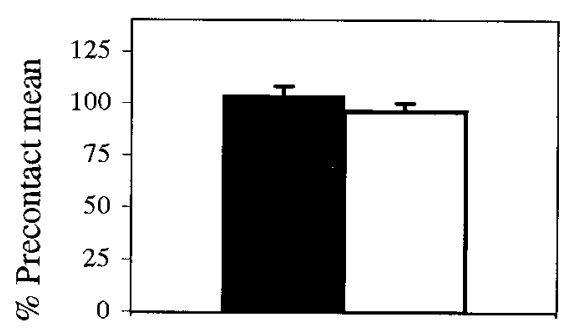

$\mathbf{E}$

Extension rate

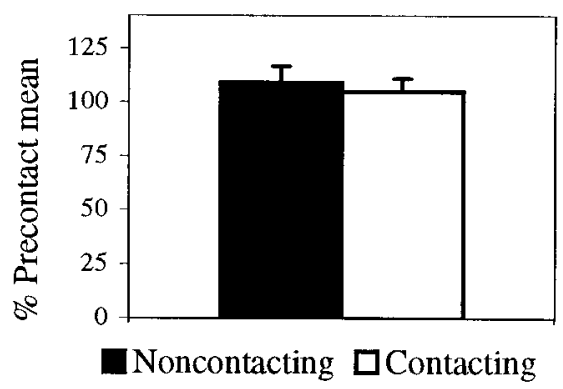

Figure 3. Contact with PS locally inhibits veil stability and extension without altering initiation frequency or rate of extension. Filopodial contact with PS reduces $(A)$ veil stability, $(B)$ veil surface area, and $(C)$ the distance that a veil extended on contacting filopodia. Contact with PS
Growth cone area

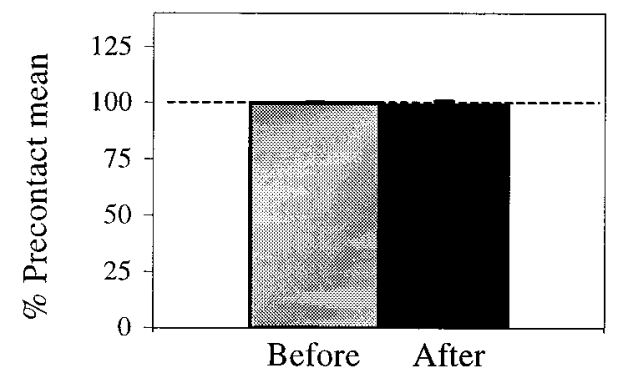

Figure 4. The mean growth cone area is unaltered by contact with PS. The gray bar represents lamellar area before stable contact. The black bar represents lamellar area after stable contact. Data were combined from six interactions ( 3 live and 3 fixed). Error bars represent SEM.

gation by $83 \%$, whereas contact with an AS cell reduced the rate of elongation by $66 \%$. Because both cell types guide sensory growth cones by different mechanisms, these observations suggest that a reduction in the rate of neurite elongation may be a common characteristic of growth cone steering, necessitated when a growth cone confronts new cues requiring it to integrate signals and alter its behavior.

\section{Filopodial dynamics}

Because filopodial contact initiates all responses, we asked whether contact with either cell type altered filopodial characteristics or fate. We found one constant: filopodial lifetime is independent of the substrate contacted. Whether filopodia were bound to the laminin substrate or to either sclerotome cell type, their lifetimes were similar (Fig. 8A). Therefore, altered extension after contact with sclerotome cells is not caused by temporal differences in filopodial lifetime. Moreover, because filopodia contacting the substrate or either cell type are interacting with different molecular environments, the duration of filopodial lifetime may be regulated intrinsically by the growth cone.

Despite stable contact, filopodia contacting PS cells exhibit morphological changes that suggest their structural integrity is compromised compared with filopodia bound to AS cells or the laminin substrate. The most obvious difference is an early, more prevalent loss in rigidity, as indicated by bending, undulations, and/or thinning (Fig. $8 B$ ). These changes are not unique to PS-bound filopodia. However, more filopodia that detached from PS cells (91\%) lost their rigidity compared with filopodia that detached from AS cells $(63 \%)$ or the laminin substrate $(28 \%)$. Moreover, filopodia bound to PS cells lost their rigidity much sooner after contact (Fig. 8C). Another particularly striking change is that nonrigid filopodia gradually thinned into a quiescent strand of membrane reminiscent of retraction fibers. As the filopodia thinned, their base often thickened, implying that material was withdrawing. These signs of structural instability suggest that cues can steer by modulating filopodial integrity in a way that may alter the ability of veils to extend down the filopodium.

Filopodia contacting AS cells exhibit a different fate: consoli-

$\leftarrow$

does not alter $(D)$ veil initiation frequency or $(E)$ the rate of veil extension on either contacting or noncontacting filopodia. Black bars represent veils extending on filopodia contacting the substrate. White bars represent veils extending on filopodia contacting a PS cell. Each bar represents at least 216 veils $(A-C, E)$ or 60 filopodia $(D)$ combined from six interactions (3 live and 3 fixed). Error bars represent SEM. ${ }^{*} p<0.001$. 

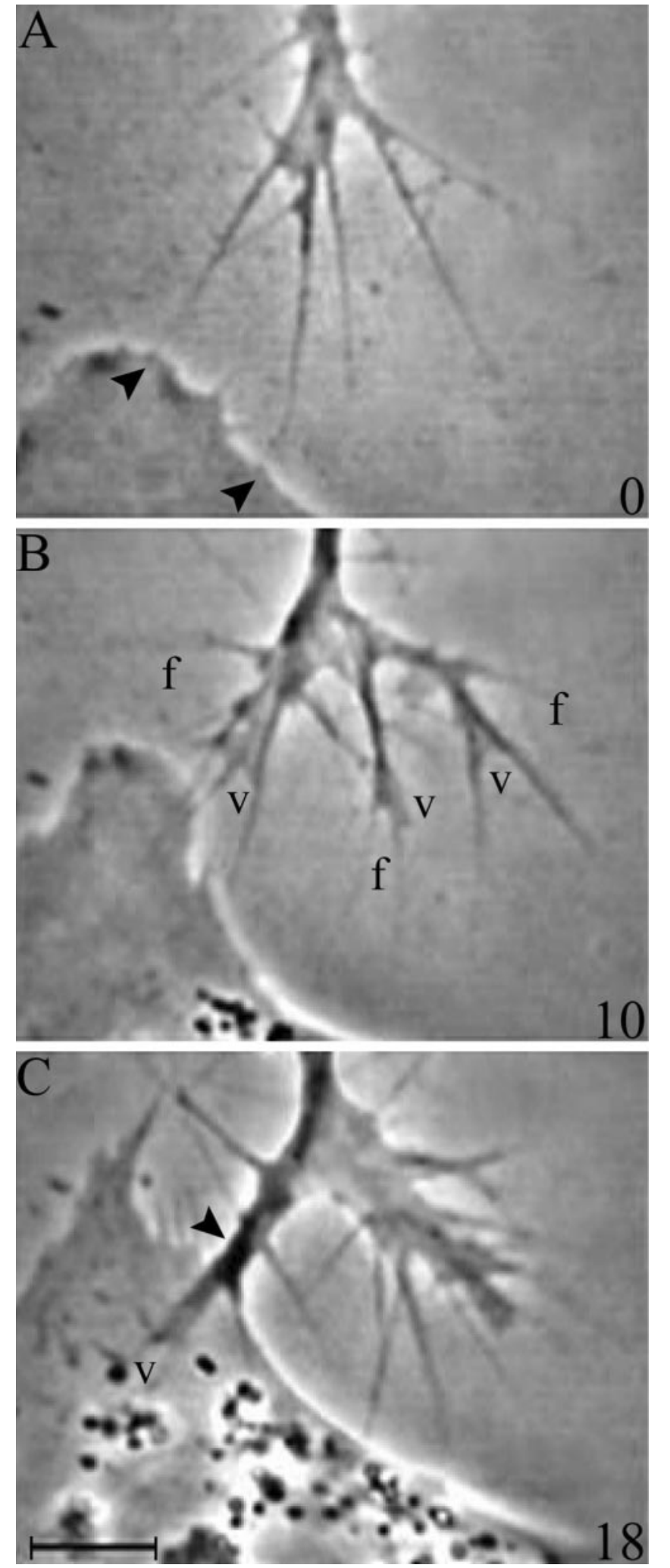

Figure 5. Contact with anterior sclerotome stimulates extension throughout the growth cone and then stimulates consolidation locally. $A$, A sensory growth cone contacts a live AS cell (arrowheads). B, Veil (v) and filopodial $(f)$ extension are stimulated globally, increasing the size and complexity of the growth cone. $C$, Consolidation is stimulated locally (arrowhead). Consolidations support new extension; a veil $(v)$ extends between filopodia over the AS cell surface. Time in minutes is indicated at the bottom right of $A-C$. Scale bar, $5 \mu \mathrm{m}$.
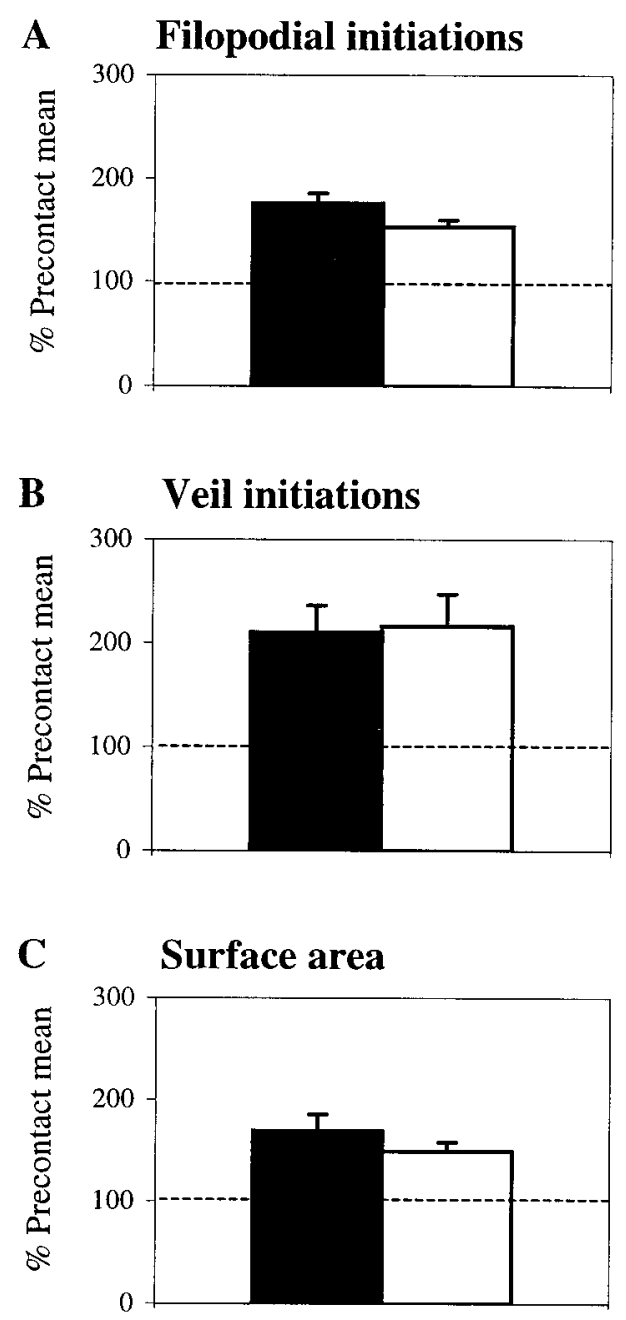

Noncontacting $\square$ Contacting

Figure 6. Contact with AS stimulates extension generally. The number of veils and filopodia extended increases throughout the growth cone; the increases are not confined to the contact site. Compared with the precontact mean, filopodial contact increases $(A)$ filopodial initiations, $(B)$ veil initiations, and $(C)$ surface area on both noncontacting and contacting sides of the growth cone $(p<0.001)$. Black bars represent values from the noncontacting side. White bars represent values from the contacting side. Data were combined from six interactions (3 live and 3 fixed). Error bars represent SEM.

dation, a complex and plastic process that culminates from a series of predictable morphological transformations (Fig. 9A). First filopodia dilate with cytoplasm, as cytoplasm engorges their base and then extends down their proximal shaft, thereby increasing their phase-dense appearance and diameter (Fig. 9A, $28 \mathrm{sec}$ ). Dilation is a rapid consequence, detectable by $1.5 \pm 0.8 \mathrm{~min}(n=$ 16) after initial contact. Then filopodia become morphologically more complex, first branching as subsidiary filopodia extend from the axis of the initial filopodium (Fig. 9A, $76 \mathrm{sec}$ ). Branching is also rapid. The first persistent branch was detectable at $2.5 \pm 1.3$ min. After branching, further complexity is generated, and the contact site is reinforced by one or more means that vary among contacts. More branches may form, additional filopodial contacts may move laterally to merge with the first, and veils may extend down filopodia and between branches. Finally, as the contact site 
A

$$
\text { Stability }
$$

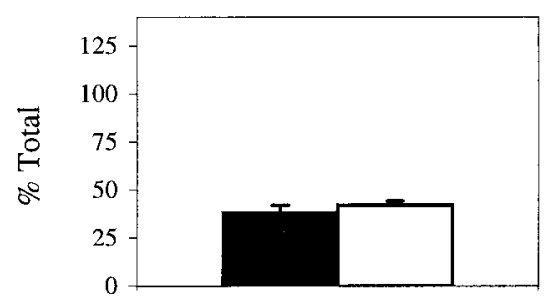

B

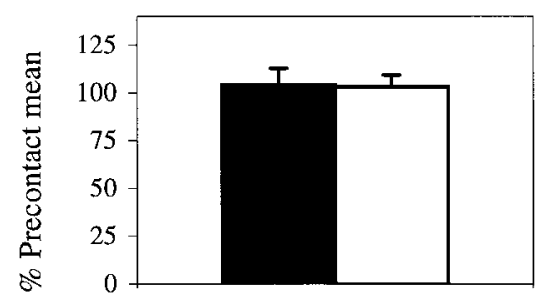

$\mathbf{C}$

\section{Distance extended}

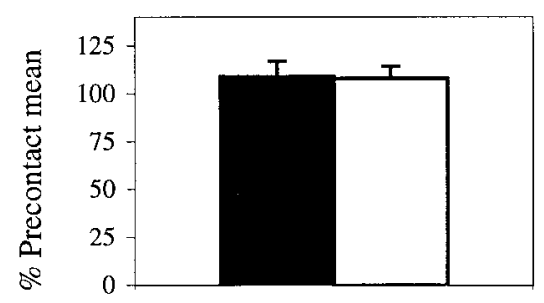

D Initiation frequency

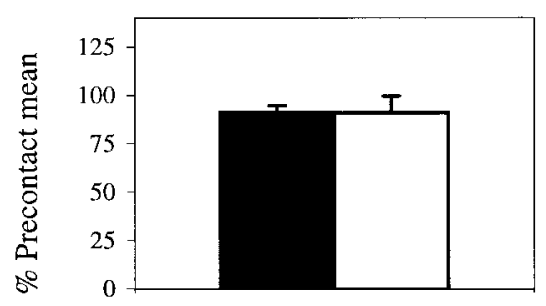

$\mathbf{E}$

Extension rate

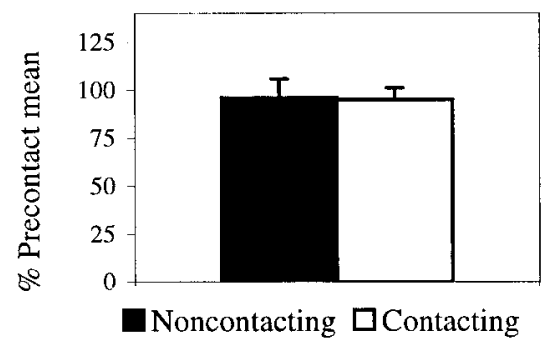

Figure 7. Despite the general increase in extension, individual veil characteristics are unchanged by contact with an AS cell. Filopodial contact does not alter $(A)$ veil stability, $(B)$ veil surface area, $(C)$ the distance a veil extended, $(D)$ veil initiation frequency per filopodium, or $(E)$ the rate of veil extension. Black bars represent veils extending on filopodia contacting the substrate only. White bars represent veils extending on filopodia contacting an AS cell. Each bar represents at least 90 veils $(B-E)$ or 40 filopodia $(A)$ combined from six interactions ( 3 live and 3 fixed). Error bars represent SEM.

\section{A Filopodial lifetime}

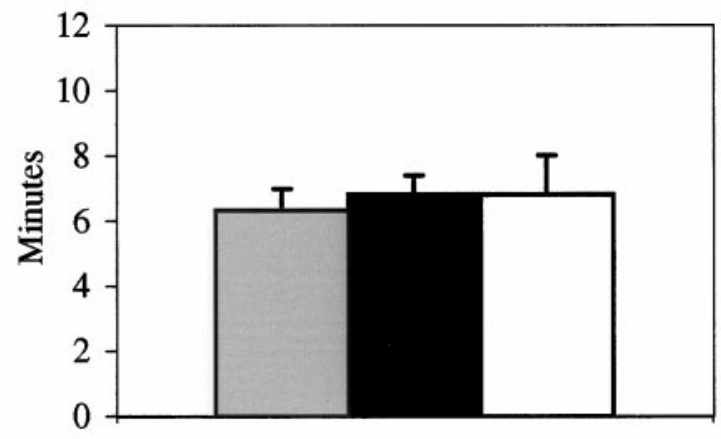

B Loss in rigidity

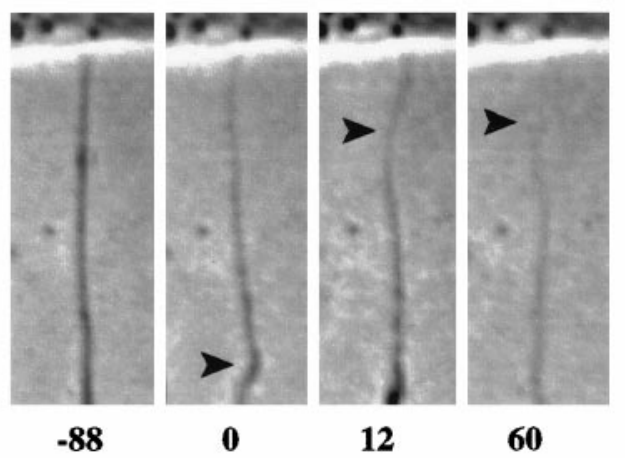

C Filopodial rigidity

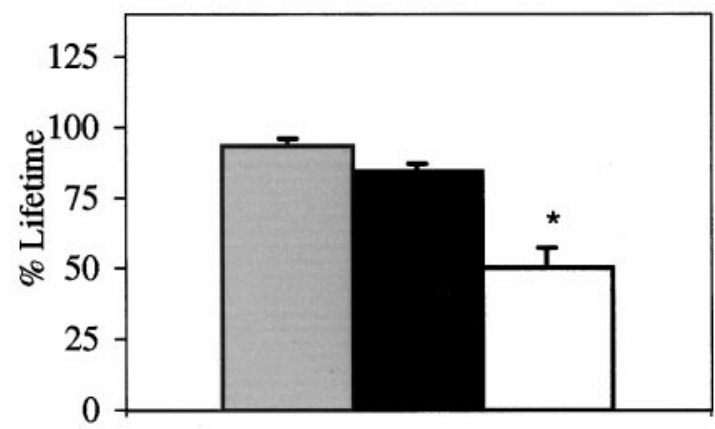

\section{口Substrate \\ Anterior sclerotome \\ 口Posterior sclerotome}

Figure 8. Filopodial lifetimes are similar for filopodia contacting the substrate, AS cells, and PS cells, but those contacting PS loose their rigidity earlier. $A$, Filopodial lifetimes are similar on the substrate (gray), AS cells (black), and PS cells (white). B, A loss in rigidity may include bending (arrowhead, $t=0 \mathrm{sec}$ ), undulations (arrowhead, $t=12 \mathrm{sec}$ ), and/or thinning (arrowhead, $t=60 \mathrm{sec}$ ). In all frames, the filopodium is attached to a sclerotome cell, visible at the top of each frame. Time in seconds before and after the initial loss in rigidity is indicated under each panel. C, Filopodia bound to PS cells (white) loose their rigidity sooner after contact than filopodia bound to the substrate (gray) or AS cells (black). Error bars represent SEM. ${ }^{*} p<0.0001$.

matures, cytoplasm from the growth cone's core fills the branch, which rounds up, becomes phase-dense, and transforms into nascent neurite (Fig. 9A, $408 \mathrm{sec}$ ). This last, consolidation phase differs morphologically from the simpler engorgement of veils with cytoplasm, a type of cytoplasmic flow that preserves the growth cone's lamellar form. 


\section{A Local consolidation}

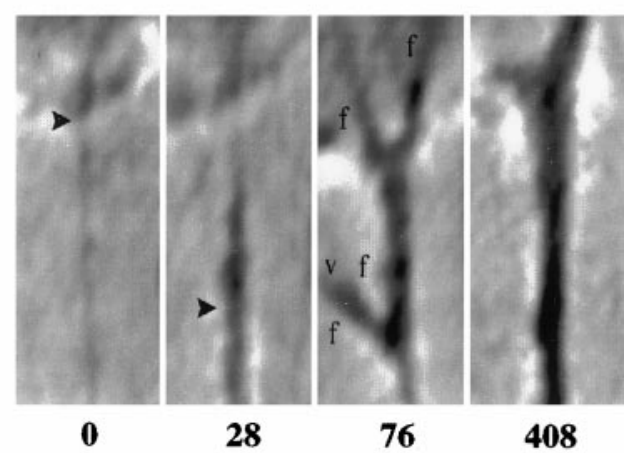

\section{B Filopodial fate}
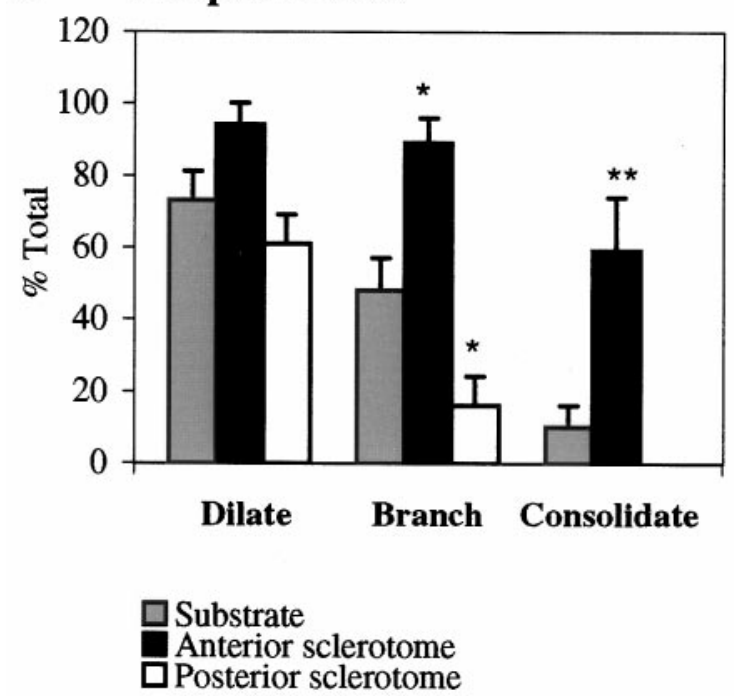

Figure 9. Filopodial fate. A, Consolidation events in filopodia contacting AS cells. Filopodia dilate at their base and subsequently down their shaft $(t=28 \mathrm{sec})$. This dilation is unusually robust; dilations more commonly filled only the proximal shaft of the filopodium initially. Filopodia then branch, extending filopodia $(f)$ from their shaft that can then support veils (v) $(t=76 \mathrm{sec})$. The branch ultimately engorges with cytoplasm to form a phase-dense, rounded neurite $(t=408 \mathrm{sec})$. In all frames, the filopodium is attached to an AS cell at the top of each frame. Time in seconds after the initial contact is indicated under each panel. B, Filopodial fates after contact with the substrate (gray), AS cells (black), or PS cells (white). Filopodia dilated with similar frequency on all contacts. Filopodia contacting PS cells branched less and never consolidated. Filopodia contacting AS cells branched and consolidated with much greater frequency. Each bar represents at least 23 filopodia from six anterior or four posterior interactions. Error bars represent SEM. * $p<0.05$; * $p<0.01$.

The consolidation of AS cell contacts can be interrupted by an evident competition for cytoplasm in which a more recent and morphologically complex contact successfully consolidates, whereas other contacts are pruned before they consolidate fully. For instance, when the fate of the first filopodium to contact an AS cell was analyzed, 1 in 16 initial filopodia failed to consolidate. This filopodium branched but remained relatively simple. A second filopodium contacting the cell 3.2 min later became more complex, consolidated, and dominated, superceding the initial contact. Although a single filopodial contact can initiate the full sequence of events, the response is usually reinforced by multiple contacts near the same site. Subsequent contacts distant from the original site will reiterate the response, sequentially producing consolidations that systematically replace each other, with an average lifetime of $15.7 \pm 5.7 \mathrm{~min}$, as the growth cone advances.

In all contacts, the initial feature, basal dilation, is similar. Even PS contacts, which fail to extend veils, consistently show basal dilation (Fig. 9B). Basal dilation itself, although it may be a source of materials required for further process extension, is thus insufficient for maturation of PS cell contacts. Interestingly, despite their inability to support veil extension, filopodia contacting PS cells retain the ability to branch, albeit at a low level, suggesting that veil and filopodial extension can be controlled differentially.

In contrast to the initial dilation, the intermediary and final phases, branching and consolidation, were enhanced significantly in AS cell contacts, in comparison to both PS and substrate contacts (Fig. 9B). Relative to substrate contacts, AS contacts showed an increase in branching of $85 \%$, whereas PS contacts showed a decrease of $67 \%$ (Table 1). Moreover, the incidence of consolidation in AS contacts was strikingly higher than in substrate contacts, increasing $490 \%$.

Substrate contacts themselves showed a progressive decline at each phase, with fewer filopodia branching than had dilated, and even fewer successfully consolidating (Fig. 9B). This relatively poor rate of consolidation typifies advance on laminin. Growth cones on laminin commonly advance as cytoplasm flows into veils, thereby preserving a spread, lamellar form. In contrast, growth cones on AS cells advance through branching and consolidation and thereby attain a streamlined, compact form.

Interestingly, for AS contacts, branching appeared to be a necessary, but insufficient phase for consolidation. On AS cells, all filopodial contacts that consolidated had first branched. Those filopodia that failed to branch also failed to consolidate, even if they had extended veils. Therefore, AS cues may act at a control point during or subsequent to branching to determine whether a filopodial contact has the potential to consolidate; e.g., initial dilation may be mediated by actin filaments, whereas branching and consolidation may require microtubule recruitment.

\section{DISCUSSION}

\section{General cues}

This study shows that general cues on different sclerotome cell types guide sensory growth cones by differentially inducing specific and invariant changes in veil and filopodial extension. Because motor growth cones also show the very same contactinduced responses (Oakley and Tosney, 1993), general cues must operate on a precise level in more than one population. Sclerotome cells may guide other populations, such as neural crest cells (Jesuthasan, 1996), by inducing similar contact-induced alterations.

\section{Cues elicit discrete responses}

Cues could influence motility stochastically, by altering motile characteristics on a probability basis, or they could influence motility selectively, by invariably altering a distinct characteristic such as the adhesion, lifetime, number, size, or stability of processes. Our data show that some cues do operate on a precise basis (summarized in Table 1). Moreover, the changes in motility induced by these cues are invariant and are thus the immediate responses that actually steer the growth cone.

Cues on sclerotome cells alter characteristics of process extension differentially. Contact with an AS cell increases the number of veils extended generally without altering individual veil characteristics such as stability, size, initiation frequency per filopodium, or extension rate. Conversely, contact with a PS cell locally 


\begin{tabular}{|c|c|c|c|c|c|c|}
\hline & Cell & Stability & Area & Distance & Frequency & Rate \\
\hline \multirow[t]{3}{*}{ Local: veils } & AS & $\mathrm{nc}$ & $\mathrm{nc}$ & $\mathrm{nc}$ & $\mathrm{nc}$ & $\mathrm{nc}$ \\
\hline & PS & $-87 \%^{\mathrm{a}}$ & $-54 \%$ & $-39 \%$ & $\mathrm{nc}$ & $\mathrm{nc}$ \\
\hline & Cell & Lifetime & Rigidity & Engorge & Branch & Consolidate \\
\hline \multirow[t]{3}{*}{ Local: filopodia } & AS & $\mathrm{nc}$ & $\mathrm{nc}$ & $\mathrm{nc}$ & $+85 \%$ & $+490 \%$ \\
\hline & PS & $\mathrm{nc}$ & $-39 \%$ & $\mathrm{nc}$ & $-67 \%$ & $\mathrm{nc}$ \\
\hline & Cell & \multicolumn{2}{|r|}{ Veil frequency } & \multicolumn{2}{|r|}{ Filopodial frequency } & Area $^{\mathrm{b}}$ \\
\hline \multirow[t]{2}{*}{ General } & AS & \multirow{2}{*}{\multicolumn{2}{|c|}{$\begin{array}{l}+113 \% \\
\text { n/a }\end{array}$}} & \multicolumn{2}{|r|}{$+75 \%$} & $+59 \%$ \\
\hline & PS & & & \multicolumn{2}{|r|}{$\mathrm{n} / \mathrm{a}$} & $\mathrm{nc}$ \\
\hline
\end{tabular}

nc, No change (ANOVA).

aPercent change compared with the precontact mean.

${ }^{\mathrm{b}}$ Growth cone area.

reduces veil stability and size without altering initiation frequency or rate. Likewise, cues can alter filopodial characteristics differentially without altering filopodial lifetimes. Contact with AS increases the number of filopodia generally without altering the rigidity of contacting filopodia. In contrast, contact with PS locally reduces the rigidity of contacting filopodia. Reduced filopodial rigidity might explain local veil inhibition directly, in accord with the notion that filopodia support veils structurally (Goldberg and Burmeister, 1986). Alternatively, cues could modulate veils or filopodia independently because their actin cytoskeletons differ structurally (Lewis and Bridgeman, 1992) and are differentially sensitive to intracellular messengers (Lankford and Letourneau, 1989) and effectors (for review, see Luo et al., 1997).

If a response to a cue is local, it will influence growth cone trajectory by increasing the growth cone's potential to extend processes in an appropriate direction. A PS contact inhibits locally and thereby directs growth away from the contact. An AS contact stimulates consolidation locally and thereby forms neurite that extends onto the cell.

Local alteration of consolidation events may be a common guidance mechanism because similar responses are described in other systems. For instance, in insects a single filopodial contact with a specific target cell induces local consolidation by filopodial dilation. The dilated filopodium then supports growth cone advance in the appropriate direction (O'Connor et al., 1990; Myers and Bastiani, 1993). Although cues in several systems can induce consolidation, they may induce it in different ways, acting at different steps during the consolidation process. Our fine dissection of consolidation events shows that the local consolidation induced by AS cells must be controlled by mechanisms independent of the veil dynamics because veil dynamics do not alter at the contact site. Moreover, an initial filopodial dilation takes place with equal facility after contact with either cell type or the substrate, suggesting that steps after the initial dilation facilitate consolidation induced by contact with AS cells.

The specific and invariant responses that we observe must be induced on contact by distinct signaling pathways. Our results discount guidance by differential filopodial adhesion alone because filopodial lifetime does not predict the responses, and morphological indications of differential filopodial fate are discernible well before filopodia detach or lose their integrity. These results complement other studies suggesting that differential growth cone adhesion is a poor predictor of substrate preference (Gunderson, 1987; Calof and Lander, 1991; Lemmon et al., 1992). Our results also discount a contact-induced release of diff usible cues that could alter extension as some neurotransmitters or intercellular messengers do in culture (Haydon et al., 1984; Goldberg, 1988; Hess et al., 1993, Zheng et al., 1996; Ming et al., 1997) because contact with fixed sclerotome cells evokes the same responses. Therefore, filopodial contact with both sclerotome cell types must initiate distinct signals that travel from the filopodial tip to the growth cone where they differentially modulate the molecular machinery driving extension. The precision and invariance with which extensions are altered in our system suggests that cues must act on distinct biochemical pathways that have very precise sites of action, altering specific cytoskeletal dynamics without altering others. If we reevaluate the effect that cues have in other systems, we may find that they also alter motile events with similar precision.

\section{Levels of extension}

Our results show that the level of veil and filopodial extension in growth cones is regulated about a set point. Despite local inhibition induced by contact with a PS cell, motor and sensory growth cones maintain their levels of extension by redirecting extension to noncontacting regions of the growth cone and neurite. Evidence from other systems also supports our idea that growth cones maintain set levels of extension. For instance, different growth cone populations can exhibit characteristic levels that are evident by their morphology. Under the same culture conditions, some populations extend broad, prominent veils and modest filopodia, whereas others extend modest veils and long, prominent filopodia (Kapfhammer and Raper, 1987; Gallo and Pollack, 1997). Moreover, levels of extension may change with developmental stage because embryonic growth cones often exhibit higher levels when compared with their postnatal counterparts (Argiro et al., 1984; Nordlander, 1987).

Our results also show that cues can alter levels of veil and filopodial extension persistently. A single brief contact with an AS cell induces persistent increases in veil and filopodial extension, suggesting that contact increases their set points. Alternatively, other cues may decrease set points. For instance, targetderived cues can persistently decrease the level of lamellar protrusion when added to cultured growth cones (Gallo and 
Pollack, 1997). Because veils comprise the motile component of lamellae, our data suggest that such lamellar alterations may stem from changes in specific veil characteristics such as veil stability or from changes in general characteristics such as the set point for extension.

Studies documenting growth cone collapse are also consistent with our interpretation that cues can reset levels of extension, in these cases to lower levels. For instance, in some systems a local contact can inhibit extension completely (Bandtlow et al., 1990; Davenport et al., 1996), halting growth cone advance presumably by resetting the set points to zero. In other systems, collapse may be induced secondarily when multiple local signals are activated additively by extensive filopodial contact (Kapfhammer and Raper, 1987; Bastmeyer and Stuermer, 1992) or by bathing the growth cone in a cue (Raper and Kapfhammer, 1987; Cox et al., 1990; Davies et al., 1990; Müller et al., 1990). Although different concentrations of the same cue might produce different degrees of inhibition, these cues are likely acting on different control points via different signaling pathways (Ivins et al., 1991; Bandtlow et al., 1993; Löschinger et al., 1997). When such cues do act only locally, the inhibition often remains local, biasing extension and thus advance away from the site of contact (Bastmeyer and Stuermer, 1992; Oakley and Tosney, 1993; Fan and Raper, 1995).

In the embryo, site-specific cues that alter set points and thus size are likely important to pathfinding because growth cones differ in size at different sites. The smallest are often found in nondecision regions such as uniform tracts, whereas the largest are often found in decision regions, regions where we know cues are directing growth cones along diverging pathways (Tosney and Landmesser, 1985; Bovolenta and Mason, 1987; Godement et al., 1994; Mason and Wang, 1997). Target regions may also harbor cues that regulate levels of extension because veil and filopodial extension decreases before synaptogenesis (Yoshihara et al., 1997). Cues that reset levels of extension could affect pathfinding simply because they change a growth cone's size. For instance, a larger growth cone could detect signals over a broader area, possibly modulating an individual signal's effect on motility because a growth cone's response depends on the combination of signals received (McCobb et al., 1988; Erskine and McCaig, 1997; Ming et al., 1997; Song et al., 1997). An increase in size could also limit signal spread and thus enhance spatial resolution.

\section{Integrating discrete responses to alter growth cone behavior}

In this study, we reduce the complex dynamics of growth cone motility to single motile events that can be analyzed independently. This focused analysis lets us show that contact with sclerotome cells repeatedly alters precise elements of extension without altering others. The precision of these alterations suggests that cues activate biochemical pathways that have very distinct readouts in their effect on motility, invariably altering precise elements of extension that modulate growth cone trajectory when integrated with other signals and the levels of extension.

The tendency to retain set levels of extension by redirecting extension can act to amplify the effect of local responses to cues. For instance, local inhibition prevents local extension, hindering movement in the direction of contact. Concurrently, extension is redirected to other sites, promoting movement away. The redirected extension is not the direct response to contact; instead it is a function of how extensively the inhibition impinges on the hierarchy of preferred extension sites. In agreement with Bray (1985), our data suggest that the preferred site for extension is the leading margin. The preference decreases centripetally from the leading edge to the sides and then the base of the growth cone, and finally to the lowest priority site, the neurite.

This integration between local inhibition and set levels of extension may explain why growth cones track alongside barriers of inhibitory cues in vitro instead of turning away from them entirely [behavior shown by Honig and Burden (1993) and Challacombe et al. (1996)], a behavior likely important to pathfinding because many neurites appear to track along less permissive tissues in several systems (Tosney and Oakley, 1990; Nordlander and Gazzerro, 1991; Bernhardt et al., 1992; Kolodkin et al., 1992; Patel et al., 1994; Burrill and Easter, 1995; Liu and Nordlander, 1995; Stoeckli et al., 1997). Once a growth cone contacts such a barrier, our model suggests that it would be inhibited only locally, preventing it from growing onto the barrier directly. However, rather than being fully repelled, it would turn only enough so that the highest priority site is free to extend. It would then tend to move in parallel with the barrier, because filopodia contacting the barrier would adhere with similar durations as those at the free edge but would not support veil extension, thus both tethering the growth cone to the barrier and preventing growth onto the barrier. Simultaneously, the permissive substrata could, like AS, actively stimulate forward advance.

\section{REFERENCES}

Argiro V, Bunge MB, Johnson MI (1984) Correlation between growth cone form and movement and their difference on neuronal age. J Neurosci 4:3051-3062.

Bandtlow C, Zachleder T, Schwab ME (1990) Oligodendrocytes arrest neurite growth by contact inhibition. J Neurosci 10:3837-3848.

Bandtlow CE, Schmidt MF, Hassinger TD, Schwab ME, Kater SB (1993) Role of intracellular calcium in NI-35-evoked collapse of neuronal growth cones. Science 259:80-83.

Bastmeyer M, Stuermer C (1992) Behavior of fish retinal growth cones encountering chick caudal tectal membranes: a time-lapse study on growth cone collapse. J Neurobiol 24:37-50.

Bentley D, Toroian-Raymond A (1986) Disoriented pathfinding by pioneer neurone growth cones deprived of filopodia by cytochalasin treatment. Nature 323:712-715.

Bernhardt RR, Nguyen N, Kuwada JY (1992) Growth cone guidance by floor plate cells in the spinal cord of zebrafish embryos. Neuron 8:869-882.

Bottenstein JE, Skaper SD, Varon SS, Sato GH (1980) Selective survival of neurons from chick embryo sensory ganglionic dissociates utilizing serum-free supplemented medium. Exp Cell Res 125:183-190.

Bovolenta P, Mason C (1987) Growth cone morphology varies with position in the developing mouse visual pathway from retina to first targets. J Neurosci 7:1447-1460.

Bray D, Chapman K (1985) Analysis of microspike movements on the neuronal growth cone. J Neurosci 5:3204-3213.

Burrill JD, Easter Jr SS (1995) The first retinal axons and their microenvironment in zebrafish: cryptic pioneers and the pretract. J Neurosci 15:2935-2947.

Calof AL, Lander AD (1991) Relationship between neuronal migration and cell-substratum adhesion: laminin and merosin promote olfactory neuronal migration but are anti-adhesive. J Cell Biol 115:779-794.

Challacombe JF, Snow DM, Letourneau PC (1996) Actin filament bundles are required for microtubule reorientation during growth cone turning to avoid an inhibitory cue. J Cell Sci 109:2031-2040.

Chien CB, Rosenthal DE, Harris WA, Holt CE (1993) Navigational errors made by growth cones without filopodia in the embryonic $\mathrm{Xe}$ nopus brain. Neuron 11:237-251.

Cox E, Müller B, Bonhoeffer F (1990) Axonal guidance in the chick visual system: posterior tectal membranes induce collapse of growth cones from the temporal retina. Neuron 2:31-37.

Davenport RW, Thies E, Nelson PG (1996) Cellular localization of guidance cues in the establishment of retinotectal topography. J Neurosci 16:2074-2085.

Davies JA, Cook GM, Stern CD, Keynes RJ (1990) Isolation from chick 
somites of a glycoprotein fraction that causes collapse of dorsal root ganglion growth cones. Neuron 2:11-20.

Erskine L, McCaig CD (1997) Integrated interactions between chondroitin sulfate proteoglycans and weak dc electric fields regulate nerve growth cone guidance in vitro. J Cell Sci 110:1957-1965.

Fan J, Raper J (1995) Localized collapsing cues can steer growth cones without inducing their full collapse. Neuron 14:263-274.

Gallo G, Pollack ED (1997) Temporal regulation of growth cone lamellar protrusion and the influence of target tissue. $\mathrm{J}$ Neurobiol 33:929-944.

Godement P, Wang L, Mason CA (1994) Retinal axon divergence in the optic chiasm: dynamics of growth cone behavior at the midline. J Neurosci 14:7024-7039.

Goldberg DJ (1988) Local role of $\mathrm{Ca}^{2+}$ in formation of veils in growth cones. J Neurosci 8:2596-2605.

Goldberg DJ, Burmeister DW (1986) Stages in axon formation: observations of growth of Aplysia axons in culture using video-enhanced contrast-differential interference contrast microscopy. J Cell Biol 103:1921-1931.

Gunderson RW (1987) Response of sensory neurites and growth cones to patterned substrata of laminin and fibronectin in vitro. Dev Biol 121:423-431.

Hamburger V, Hamilton HL (1951) A series of normal stages in the development of the chick embryo. J Morphol 88:49-92.

Haydon PG, McCobb DP, Kater SB (1984) Serotonin selectively inhibits growth cone motility and synaptogenesis of specific identified neurons. Science 226:561-564.

Hess DT, Patterson SI, Smith DS, Skene JH (1993) Neuronal growth cone collapse and inhibition of protein fatty acylation by nitric oxide. Nature 366:562-565.

Honig MG, Burden SM (1993) Growth cones respond in diverse ways upon encountering neurites in cultures of chick dorsal root ganglia. Dev Biol 156:454-472.

Ivins JK, Raper JA, Pittman RN (1991) Intracellular calcium levels do not change during contact-mediated collapse of chick DRG growth cone structure. J Neurosci 11:1597-1608.

Jesuthasan S (1996) Contact inhibition/collapse and pathfinding of neural crest cells in the zebrafish trunk. Development 122:381-389.

Kapfhammer JP, Raper JA (1987) Collapse of growth cone structure on contact with specific neurites in culture. J Neurosci 7:201-212.

Kolodkin AL, Matthes DJ, O'Connor TP, Patel NH, Admon A, Bentley D, Goodman CS (1992) Fasciclin IV: sequence, expression, and function during growth cone guidance in the grasshopper embryo. Neuron 9:831-845.

Lankford KL, Letourneau PC (1989) Evidence that calcium may control neurite outgrowth by regulating the stability of actin filaments. J Cell Biol 109:1229-1243.

Lemmon V, Burden SM, Payne R, Elmslie GJ, Hlavin ML (1992) Neurite growth on different substrates: permissive versus instructive influences and the role of adhesive strength. J Neurosci 12:818-826.

Lewis A, Bridgeman P (1992) Nerve growth cone lamellipodia contain two populations of actin filaments that differ in organization and polarity. J Cell Biol 119:1219-1243.

Liu S, Nordlander RH (1995) Growth cones and axon trajectories of the earliest descending serotonergic pathway of Xenopus. Neuroscience 69:309-320.

Löschinger J, Bandtlow CE, Jung J, Klostermann S, Schwab ME, Bonhoeffer F, Kater SB (1997) Retinal axon growth cone responses to different environmental cues are mediated by different secondmessenger systems. J Neurobiol 33:825-834.
Luo L, Jan LY, Jan YN (1997) Rho family GTP-binding proteins in growth cone signaling. Curr Opin Neurobiol 7:81-86.

Marsh L, Letourneau P (1984) Growth of neurites without filopodial or lamellipodial activity in the presence of cytochalasin B. J Cell Biol 99:2041-2047.

Mason CA, Wang L (1997) Growth cone form is behavior-specific and, consequently, position-specific along the retinal axon pathway. J Neurosci 17:1086-1100.

McCobb DP, Cohan CS, Connor JA, Kater SB (1988) Interactive effects of serotonin and acetylcholine on neurite elongation. Neuron 1:377-385.

Meiri KF, Burdick D (1991) Nerve growth factor stimulation of GAP-43 phosphorylation in intact isolated growth cones. $\mathrm{J}$ Neurosci 11:3155-3164.

Ming $\mathrm{G}$, Song $\mathrm{H}$, Berninger B, Holt CE, Tessier-Lavigne M, Poo M (1997) cAMP-dependent growth cone guidance by netrin-1. Neuron 19:1225-1235.

Müller B, Stahl B, Bonhoeffer F (1990) In vitro experiments on axonal guidance and growth-cone collapse. J Exp Biol 153:29-46.

Myers PZ, Bastiani MJ (1993) Growth cone dynamics during the migration of an identified commissural growth cone. J Neurosci 13:127-143.

Nordlander RH (1987) Axonal growth cones in the developing amphibian spinal cord. J Comp Neurol 263:485-496.

Nordlander RH, Gazzerro JW, Cook H (1991) Growth cones and axon trajectories of a sensory pathway in the amphibian spinal cord. J Comp Neurol 307:539-548.

Oakley R, Tosney KT (1993) Contact mediated mechanisms of motor axon segmentation. J Neurosci 13:3773-3792.

O'Connor T, Duerr J, Bentley D (1990) Pioneer growth cone steering decisions mediated by single filopodial contacts in situ. J Neurosci 10:3935-3946.

Patel CK, Rodriguez LC, Kuwada JY (1994) Axonal outgrowth within the abnormal scaffold of brain tracts in a zebrafish mutant. J Neurobiol 25:345-360.

Raper J, Kapfhammer J (1987) The enrichment of a neuronal growth cone collapsing activity from embryonic chick brain. Neuron 4:21-29.

Smith C (1994) Cytoskeletal movements and substrate interactions during initiation of neurite outgrowth by sympathetic neurons in vitro. J Neurosci 14:384-398.

Song HJ, Ming GL, Poo MM (1997) cAMP-induced switching in turning direction of nerve growth cones. Nature 388:275-279.

Stoeckli ET, Sonderegger P, Pollerberg GE, Landmesser LT (1997) Interference with axonin-1 and NrCAM interactions unmasks a floorplate activity inhibitory for commissural axons. Neuron 18:209-221.

Tannahill D, Cook GMW, Keynes RJ (1997) Axon guidance and somites. Cell Tissue Res 290:275-283.

Tosney KT (1991) Cells and cell interactions that guide motor axons in the developing chick embryo. BioEssays 13:17-23.

Tosney KT, Landmesser L (1985) Growth cone morphology and trajectory during outgrowth into the chick limb. J Neurosci 5:2345-2358.

Tosney KW, Oakley RA (1990) The perinotochordal mesenchyme acts as a barrier to axon advance in the chick embryo: implications for a general mechanism of axonal guidance. Exp Neurol 109:75-89.

Yoshihara M, Rheuben MB, Kidokoro Y (1997) Transition from growth cone to functional motor nerve terminal in Drosophila embryos. J Neurosci 17:8408-8426.

Zheng JQ, Wan J, Poo M (1996) Essential role of filopodia in chemotropic turning of nerve growth cone induced by a glutamate gradient. J Neurosci 16:1140-1149. 